\section{Analisis Yuridis Notaris Sebagai Pihak Pelapor Dalam Pencegahan Dan Pemberantasan Tindak Pidana Pencucian Uang (Studi Pasal 3 huruf (b) PP RI Nomor 43 Tahun 2015 Tentang Pihak Pelapor Dalam Pencegahan dan Pemberantasan Tintak Pidana Pencucian Uang)}

Oleh : then to carry out the reporting to the PPATK, the notary is obliged to register and fill in the report by assigning a reporting officer, registering through the Gathering Reports and Information Processing System (GRIPS) application.

Keywords : Notary, Prevention, Eradication, Money Laundering.

\section{Abstrak}

Keluarnya Peraturan Pemerintah Nomor 43 Tahun 2015 Tentang Pihak Pelapor Dalam Pencegahan Dan Pemberantasan Tindak Pidana Pencucian Uang, sebagaimana dalam Pasal 3 Peraturan Pemerintah ini ditegaskan bahwa notaris sebagai pihak pelapor atas dugaan tindak pidana pencucian uang atas akta yang dibuatnya. Bila kewajiban pelaporan ini tidak dilaksanakan notaris, dan akta yang dibuatnya terkait tindak pidana pencucian uang, menurut ketentuan Pasal 5 Undang-Undang Nomor 8 Tahun 2010 Tentang Pencegahan Dan Pemberantasan Tindak Pidana Pencucian Uang, akan terkena sanksi pidana dan denda. Berkaitan dengan hal ini, perlu dikaji lebih dalam pertimbangan memasukkan notaris sebagai pihak pelapor dalam pencegahan dan pemberantasan tindak pidana pencucian uang terhadap akta yang dibuatnya.

Notaris dilibatkan sebagai pihak pelapor dalam pencegahan dan pemberantasan tindak pidana pencucian uang karena belum/tidak maksimalnya pencegahan dan pemberantasan tindak pidana pencucian uang di Indonesia dengan modus pencucian uang yang semakin canggih karena memanfaatkan profesi notaris sebagai sarana pencucian uang oleh pelaku pencucian uang untuk memuluskan aksinya terhadap uang yang diperoleh dari hasil kejahatan dan dengan dilibatkannya notaris.Mekanisme pelaksanaan pelaporan oleh notaris sebagai pihak pelapor tindak pidana pencucian uang. Pertama pihak pelapor wajib menerapkan prinsip mengenali pengguna jasa kemudian untuk melaksanakan pelaporan kepada PPATK notaris wajib melakukan registrasi dan pengisian laporan dengan menetapkan petugas pelaporan, melakukan

1 Mahasiswa Magister Hukum Fakultas Hukum Universitas Islam Sumatera Utara. 
Media Komunikasi dan Informasi Hukum dan Masyarakat

registrasi melalui aplikasi Gathering Reports and Information Processing System (GRIPS).

Kata Kunci : Notaris, Pencegahan, Pemberantasan, Pencucian uang.

\section{Pendahuluan}

\section{A. Latar Belakang}

Salah satu kejahatan white collar crime yang mendapat perhatian khusus dari dunia internasional termasuk Indonesia adalah tindak pidana pencucian uang (TPPU) atau yang lebih dikenal dengan istilah money laundering. Mengenai apa yang dimaksud dengan pencucian uang atau money laundering sampai sekarang masih belum terdapat definisi atau pengertian yang universal dan komprehensif. ${ }^{2}$

Definisi atau pengertian TPPU telah banyak diutarakan oleh para ahli hukum, salah satunya adalah Sutan Remy Sjahdeini mendefinisikan TPPU atau money Laundering sebagai rangkaian kegiatan yang dilakukan oleh perorangan maupun korporasi untuk menyembunyikan atau menyamarkan uang haram dengan cara memasukkan uang tersebut ke dalam sistem keuangansehingga uang tersebut kemudian dapat tampak sepert uang yang halal ketika dikeluarkan dari sistem keuangan tersebut. Sutan Remy Sjahdeini menambahkan tujuan utama pelaku pencucian uang adalah untukmenghindari tindakan para penegak hukum yang mengancam harta haram tersebut. $^{3}$ Menurut Nicholas Clark pada umumnya proses pencucian uang terdiri dari

2 R. Wiyono, Pembahasan Undang-Undang Pencegahan dan Pemberantasan Tindak Pidana Pencucian Uang, Sinar Grafika, Jakarta, 2014, hal. 21.

3 Sutan Remy Sjahdeini, Seluk-Beluk Tindak Pidana Pencucian Uang dan Pembiayaan Terorisme, Jakarta, Pustaka Utama Grafiti, 2007, hal. 5. tiga tahap yaitu placement, layering dan integration. $^{4}$

Dalam perkembangannya untuk mencegah dan memberantas tindak pidana pencucian uang dibentuklah Undang-undang Nomor 8 tahun 2010 tentang Pencegahan dan Pemberantasan Tindak Pidana Pencucian Uang (UU PPTPPU). Walaupun sudah dua kali mengalami perubahan, UU PPTPPU ini dinilai masih kurang optimal dalam mencegah dan memberantas TPPU. Salah satu kelemahan yangada di UU PPTPPU adalah sempitnya cakupan pihak pelapor ${ }^{5}$ yang diwajibkan untuk melaporkan transaksi keuangan mencurigakankepada Pusat Pelaporan dan Analisis Transaksi Keuangan (PPATK). Pihak Pelapor merupakan pihak yang penting dalam melakukan pencegahan dan pemberantasan TPPU mengingat pihak pelaporlah yang berhadapan secara langsung dengan pelaku kejahatan yang ingin melakukan pencucian uang. Peran penting yang dimainkan oleh pihak pelapor dalam pemberantasan dan pencegahan TPPU ini dikarenakan UU PPTPPU memberikan beberapa kewajiban pokok yang harus dilakukan oleh pihak pelapor, kewajiban pertama adalah pihak pelapor wajib menerapkan prinsip mengenali pengguna jasa (Know Your Consumer). Melalui penerapan Prinsip Mengenali Pengguna Jasa ini pelapor berkewajiban melakukan identifikasi dan verivikasi Pengguna, kewajiban kedua yang dibebankan kepada pihak pelapor adalah adanya kewajiban bagi pihak pelapor untuk melaporkan apabila adanya transaksi keuangan

${ }^{4}$ Nicholas Clark, The Impact of Recent Money Laundering Legislation on Financial Intermediaries, Dick J. Int'l.L, vol. 14 , hal. 470 .

${ }^{5}$ Menurut pasal 1 angka 11 UU PPTPPU definisi pihak pelapor adalah Setiap Orang yang menurut UndangUndang (Pasal 17 ayat 1 UU PPTPPU) ini wajib menyampaikan laporan kepada PPATK. 
Media Komunikasi dan Informasi Hukum dan Masyarakat

mencurigakan yang dilakukan oleh pengguna jasa. ${ }^{6}$

Keluarnya Peraturan Pemerintah Nomor 43 Tahun 2015 Tentang Pihak Pelapor Dalam Pencegahan dan Pemberantasan Tindak Pidana Pencucian Uang, sebagaimana dalam Pasal 3 Peraturan Pemerintah ini ditegaskan bahwa notaris sebagai pihak pelapor atas dugaan tindak pidana pencucian uang atas akta yang dibuatnya.

Peraturan Pemerintah ini merupakan peraturan pelaksana ketentuanPasal 17 ayat (2) Undang-Undang Nomor 8 Tahun 2010 Tentang Pencegahan Dan Pemberantasan Tindak Pidana Pencucian Uang.Pasal 8 Ayat (1) Peraturan Pemerintah Nomor 43 Tahun 2015 Tentang Pihak Pelapor Dalam Pencegahan Dan Pemberantasan Tindak Pidana Pencucian Uang menegaskan bahwa "Pihak Pelapor sebagaimana dimaksud dalam Pasal 3 wajib menyampaikan laporan Transaksi Keuangan Mencurigakan kepada PPATK untuk kepentingan atau untuk dan atas nama Pengguna Jasa, mengenaipembelian dan penjualan properti, pengelolaan terhadap uang, efek, dan/atau produk jasa keuangan lainnya, pengelolaan rekening giro, rekening tabungan, rekening deposito, dan/atau rekening efek, pengoperasian dan pengelolaan perusahaan; dan/ataupendirian, pembelian, dan penjualan badan hukum". ${ }^{7}$

Peraturan Pemerintah ini mewajibkan notaris harus melaporkan ke PPATK (Pusat

6 Fithriadi Muslim, Journal on anti money Laundering,"Fungsi Laporan TransaksiKeuangan Mencurigakan Dalam Pencegahan Dan Pemberantasan Tindak Pidana Pencucian Uang", Depok, Pusat Kajian Anti Pencucian Uang Indonesia Indonesia Research Center for AML- CFT (IRCA), 2013, hal. 15.

7 Peraturan Pemerintah Nomor 43 Tahun 2015 Tentang Pihak Pelapor Dalam Pencegahan Dan Pemberantasan Tindak Pidana Pencucian Uang.
Pelaporan dan Analisis Transaksi Keuangan) terkait adanya dugaan tindak pidana pencucian uang atas akta yang dibuat oleh atau dihadapan notaris selaku pejabat umum. Bila kewajiban pelaporan ini tidak dilaksanakan notaris, dan akta yang dibuatnya terkait tindak pidana pencucian uang, menurut ketentuan Pasal 5 Undang-Undang Nomor 8 Tahun 2010 Tentang Pencegahan dan Pemberantasan Tindak Pidana Pencucian Uang, akan terkena sanksi pidana dan denda. Berkaitan dengan hal ini, perlu dikaji lebih dalam pertimbangan memasukkan notaris sebagai pihak pelapor dalam pencegahan dan pemberantasan tindak pidana pencucian uang terhadap akta yang dibuatnya.

Berdasarkan hal ini perlu dikaji lebih dalam dengan diadakannya penelitian untuk mengetahui notarissebagai pihak pelapor dalam pencegahan dan pemberantasan tindak pidana pencucian uang.

\section{B. Rumusan Masalah}

Berdasarkan latar belakang yang telah diuraikan diatas, maka rumusan masalah yang dapat dikaji dalam penelitian ini adalah sebagai berikut:

1. Mengapa Notaris dilibatkan sebagai pihak pelapor dalam pencegahan dan pemberantasan tindak pidana pencucian uang berdasarkan PP No.43 Tahun 2015?

2. Bagaimanakah pelaksanaan pelaporan notaris sebagai pihak pelapor tindak pidana pencucian uang ?

3. Bagaimanakah perlindungan hukum terhadap notaris sebagai pihak pelapor tindak pidana pencucian uang? 
Media Komunikasi dan Informasi Hukum dan Masyarakat

\section{Metode Penelitian}

Penelitian ini bersifat deskriptif analitis, yaitu suatu metode yang digunakan untuk menggambarkan dan menganalisis mengenai situasi atau kejadian dan menerangkan hubungan antara kejadian tersebut dengan masalah yang akan diteliti.

Jenis penelitian yang digunakan dalam penelitian ini adalah metode penelitian hukum yuridis normatif yaitu penelitian hukum yang mengkaji norma-norma hukum yang bersumber dari peraturan perundang-undangan.

Dalam penelitian ini, norma hukum yang dikaji adalah bersumber dari Pasal 3 huruf (b) PP RI Nomor 43 Tahun 2015 Tentang Pihak Pelapor Dalam Pencegahan dan Pemberantasan Tintak Pidana Pencucian Uang.

\section{Hasil dan Penelitian}

\section{A. Alasan Notaris Dilibatkan Sebagai Pihak Pelapor Dalam Pencegahan dan Pemberantasan Tindak Pidana Pencucian Uang}

Paradigma follow the money ${ }^{8}$ ini dalam memberantas tindak pidana pencucian uang kurang efektif apabila tidak didukung dengan adanya laporan-laporan transaksi keuangan mencurigakan yang dilakukan oleh pihak pelapor. Laporan TKM ini merupakan salah satu unsur yang paling efektif dalam pencegahan dan pemberantasan TPPU. Laporan TKM yang

${ }^{8}$ follow the money ("menelusuri aliran uang") merupakan pendekatan baru untuk memberantas tidak pidana pencucian uang, pendekatan ini lebih mudah dibandingkan dengan pendekatan konvensional yang mengejar pelaku tindak pidana atau follow the suspect karena pelaku atau saksi bisa saja berkata bohong, tetapi aliran uang tidak akan bisa ditutup-tutupi. Paradigma baru dalam penanganan kejahatan ini juga memudahkan penegak hukum untuk menelusuri tindak pidana pencucian uang serta tindak pidana lain dan tujuan yang paling utama adalah mengembalikan kerugian negara yang dilakukan oleh pelaku kejahatan. Perlu dicatat bahwa hasil-hasil kejahatan merupakan "lifeblood of the crime". diberikan oleh pihak pelapor kepada PPATK merupakan langkah awal bagi PPATK untuk menelusuri para pelaku yang terlibat dalam pencucian uang serta menelusuri aliran dana yang dilakukan pelaku TPPU. Dengan mengetahui aliran dana TKM juga sangat membantu aparat penegak hukum untuk mengungkap aktor-aktor dibalik tindak pidana pencucian uang yang dilakukan oleh pelaku kejahatan.

Dampak dari Notaris dan PPAT yang tidak dikategorikan sebagai pihak pelapor adalah Notaris dan PPAT tidak berkewajiban untuk melaporkan transaksi keuangan mencurigakan yang dilakukan oleh pengguna jasa. Padahal modus pencucian uang dengan menggunakan modus jual belireal estate sedang marak terjadi di Indonesia. Dengan tidak melaporkan adanya transaksi keuangan mencurigakan maka aparat penegak hukum akan kesulitan dalam melakukan pencegahan dan pemberantasan tindak pidana pencucian uang. Padahal pada asasnya pembangunan rezim anti pencucian yang kuat membutuhkan kerja sama antara pihak pelapor, masyarakat, serta aparat penegak hukum.

Modus operandi dari pencucian uang yang semakin canggih karena memanfaatkan profesional di bidang keuangan atau hukum dengan keahlian, pengetahuan, dan akses khusus kepada sistem keuangan global, yang mencoba memanfaatkan peluang melalui keahlian mereka untuk mengamankan hasil tindak pidana. Salah satu bentuk TKM yang menjadi modus pelaku TPPU adalah bisnis jual beli real estate dan perumahan.

Seiring dengan semakin ketatnya lembaga-lembaga perbankan membuat para pelaku TPPU untuk mengalihkan modus 
Media Komunikasi dan Informasi Hukum dan Masyarakat

pencucian uangnya ke jual beli real estate/ tanah dan/atau bangunan. Setidaknya ada dua faktor pendukung mengapa pelaku lebih banyak menggunakan modus pencucian uang dengan cara jual beli real estate yaitu, pertama real estate merupakan salah satu bentuk investasi yang sangat menjanjikan karena nilai ekonomisnya terus mengalami peningkatan.

Faktor pendukung kedua mengapa pelaku TPPU menggunakan modus pencucian uang melalui penggunaan jasa Notaris karena kedua profesi ini dianggap tidak dikategorikan sebagai pihak pelapor dalam UU PPTPPU. Tidak seperti lembaga perbankan dan lembaga pembiayaan yang dikategorikan sebagai pihak pelapor yang wajib menyampaikan laporan apabila terdapat TKM.

pihak pelapor dalam membantu penegakan hukum khususnya UU PPTPPU. Dengan mendasarkan pada laporan dan/atau informasi dari Pihak Pelapor, instansi, atau pihak terkait lainnya, selanjutnya PPATK melakukan analisis apakah benar transaksi yang dilaporkan oleh pihak pelapor tadi betul merupakan transaksi yang bertujuan untuk melakukan pencucian uang. Dengan mengetahui aliran dana TKM juga sangat membantu aparat penegak hukum untuk mengungkap aktor-aktor dibalik tindak pidana pencucian uang yang dilakukan oleh pelaku kejahatan.

\section{B. Proses Pelaksanaan Pelaporan Oleh Notaris Sebagai Pihak Pelapor Tindak Pidana Pencucian Uang}

Dalam ketentuan Pasal 3 PP 43/2015 dinyatakan bahwa profesi-profesi tertentu seperti Advokat, Notaris, Pejabat Pembuat Akta Tanah, Akuntan, Akuntan Publik, dan
Perencana Keuangan termasuk ke dalam bagian Pihak Pelapor yang wajib dan turut mencegah dan memberantas tindak pidana pencucian uang. Oleh karena itu, para profesi khususnya Notaris sebagai Pihak Pelapor perlu melakukan upaya pencegahan yang lebih mendalam. Sebagaimana yang termuat dalam ketentuan Pasal 4 Peraturan Pemerintah yang menyebutkan bahwa "Pihak Pelapor wajib menerapkan prinsip mengenali Pengguna Jasa".

Prinsip mengenali pengguna jasa bagi Pihak Pelapor berlaku secara mutatis mutandis yang artinya bahwa berlaku juga perubahanperubahan yang diperlukan terhadap penerapan prinsip mengenali Pengguna Jasa bagi Pihak Pelapor. Dalam Pasal 18 UU TPPU, diatur penerapan prinsip mengenali pengguna jasa, sebagai berikut:

Pasal 18

(1) Lembaga Pengawas dan Pengatur menetapkan ketentuan prinsip mengenali Pengguna Jasa.

(2) Pihak Pelapor wajib menerapkan prinsip mengenali Pengguna Jasa yang tetapkan oleh setiap Lembaga Pengawas dan Pengatur sebagaimana dimaksud pada ayat (1)

(3) Kewajiban menerapkan prinsip mengenali Pengguna Jasa sebagaimana dimaksud pada ayat (2) dilakukan pada saat:

a. Melakukan hubungan usaha dengan Pengguna Jasa;

b. Terdapat Transaksi Keuangan Mencurigakan dengan mata uang rupiah dan/ atau mata uang asing yang nilainya paling sedikit atau setara dengan Rp100.000.000,00 (seratus juta rupiah); 
Media Komunikasi dan Informasi Hukum dan Masyarakat

c. Terdapat Transaksi Keuangan

Mencurigakan yang terkait tindak pidana Pencucian Uang dan tindak pidana pendanaan terorisme; atau

d. Pihak Pelapor meragukan kebenaran informasi yang dilaporkan Pengguna Jasa.

(4) Lembaga Pengawas dan Pengatur wajib melaksanakan pengawasan atas kepatuhan Pihak Pelapor dalam menerapkan prinsip mengenali Pengguna Jasa.

(5) Prinsip mengenali Pengguna Jasa sekurang-kurangnya memuat:
a. Identifikasi Pengguna Jasa;
b. Verifikasi Pengguna Jasa; dan
c. Pemantauan Transaksi Pengguna Jasa.

(6) Dalam hal belum terdapat Lembaga Pengawas dan Pengatur, ketentuan mengenai prinsip mengenali Pengguna Jasa dan pengawasannya diatur dengan Peraturan Kepala PPATK.

Oleh karena itu, dalam rangka mengenali pengguna jasa baik terhadap orang-perorangan, korporasi maupun perikatan lainnya diperlukan tindakan Notaris untuk melakukan pengumpulan informasi dengan meneliti kebenaran dokumen identitas Pengguna Jasa seperti Kartu Tanda Penduduk, Nomor Pokok Wajib Pajak, dan spesimen tanda tangan Pengguna Jasa. Selain meneliti kebenaran dokumen formil tersebut untuk benar-benar meyakini identitas Pengguna Jasa, maka Notaris juga diwajibkan bertemu langsung dengan Pengguna Jasa.

laporannya atas dugaan transaksi keuangan mencurigakan kepada PPATK, maka untuk memberikan kepastian hukum PPATK menerbitkan Peraturan Kepala Pusat Pelaporan dan Analisis Transaksi Keuangan Nomor 11 Tahun 2016 tentang Tata Cara Penyampaian Laporan Transaksi Keuangan Mencurigakan
Bagi Profesi (selanjutnya disebut Perka PPATK 11/2016). Dalam Perka PPATK 11/2016, diatur mengenai kewajiban pelaporan transaksi keuangan mencurigakan yang wajib dilaporkan kepada PPATK yang dilakukan oleh Profesi untuk kepentingan atau untuk dan atas nama Pengguna Jasa, mengenai:

a. Pembelian dan penjualan properti;

b. Pengelolaan terhadap uang, efek, dan/ atau produk jasa keuangan lainnya;

c. Pengelolaan rekening giro, rekening tabungan, rekening deposito, dan/ atau rekening efek;

d. Pengoperasian dan pengelolaan perusahaan; dan/ atau

e. Pendirian, pembelian, dan penjualan badan hukum. ${ }^{9}$

Kemudian, untuk melaksanakan pelaporan kepada PPATK, Profesi wajib melakukan registrasi dan pengisian laporan, yang ketentuannya diatur lebih lanjut dalam ketentuan Pasal 6 Perka PPATK 11/2016, antara lain:

a. Menetapkan petugas pelaporan;

Penetapan petugas pelaporan, wajib dilakukan oleh Profesi dengan menetapkan: petugas pendaftar, petugas pelapor, petugas administrasi dan petugas penghubung. Petugas tersebut dapat melakukan rangkap jabatan apabila Profesi merupakan orang perseorangan atau Profesi merupakan Korporasi dengan memperhatikan aspek pengendalian intern. ${ }^{10}$

${ }^{9}$ Pasal 3 Ayat (1) Peraturan Menteri Hukum dan Hak Asasi Manusia Republik Indonesia Nomor 9 Tahun 2017 Tentang Penerapan Prinsip Mengenal Pengguna Jasa Bagi Notaris.

${ }_{10}$ Pasal 7 Peraturan Menteri Hukum dan Hak Asasi Manusia Republik Indonesia Nomor 9 Tahun 2017 
Media Komunikasi dan Informasi Hukum dan Masyarakat

b. Melakukan registrasi melalui aplikasi GRIPS;

Dalam melakukan registrasi, Profesi wajib mengakses website aplikasi GRIPS pada alamat website https://grips2.ppatk.go.id. Selanjutnya, diperlukan pengisian registrasi melalui 4 (empat) langkah besaran, yakni:

1) pengisian data perusahaan,

2) pengisian data petugas,

3) pengisian data pendukung, dan

4) pengisian data petugas pendaftar.

Secara lebih lanjut hal tersebut dapat dilihat dalam gambar terlampir di bawah ini:

Registrasi tersebut meliputi nama Profesi, bentuk usaha, nomor NPWP, kategori Profesi, dan data petugas. Setelah, registrasi selesai dilakukan, maka Profesi wajib menyampaikan hasil registrasi yang telah diotorisasi paling lama 7 (tujuh) hari kerja yang ditunjukan kepada Kepala PPATK Up Direktur Pelaporan. ${ }^{11}$

c. Melakukan pelaporan ke PPATK. Laporan transaksi keuangan mencurigakan wajib memuat informasi paling sedikit mencakup orang-perorangan, korporasi, rincian transaksi yang dilaporan, informasi lainnya, dan identitas beneficial owner orang perseorangan/ korporasi. Pengisian laporan transaksi keuangan mencurigakan dilakukan melalui Aplikasi GRIPS yang dilakukan oleh Petugas Pelapor dengan cara mengisi (entry) secara manual laporan transaksi keuangan mencurigakan pada Aplikasi GRIPS, atau mengunggah (upload) file ke Aplikasi GRIPS dalam format Microsoft

Tentang Penerapan Prinsip Mengenal Pengguna Jasa Bagi Notaris.

11 Pasal 8 Peraturan Menteri Hukum dan Hak Asasi Manusia Republik Indonesia Nomor 9 Tahun 2017 Tentang Penerapan Prinsip Mengenal Pengguna Jasa Bagi Notaris.
Excel. Selanjutnya, penyampaian laporan transaksi keuangan mencurigakan wajib disampaikan secara elektronis melalui Aplikasi GRIPS ke jaringan telekomunikasi yang ditunjukan langsung ke database PPATK melalui web based application.

\section{Perlindungan Hukum Kepada Notaris Menurut Undang-Undang Tindak Pidana Pencucian Uang.}

laporan yang diberikan oleh pelapor kepada aparat penegak hukum adalah perbuatan yang mengandung resiko yang besar terhadap keselamatan dirinya, keluarganya serta harta benda miliknya sehingga Negara harus dapat memberikan kepastian hukum mengenai perlindungan hukum yang diberikan kepada pelapor beserta keluarganya. Perlindungan hukum bagi pihak pelapor atas transaksi keuangan mencurigakan terkait tindak pidana pencucian uang dibagi menjadi dua yaitu sebelum berlakunya Tindak Pidana Pencucian Uang (TPPU) dan sesudah berlakunya Tindak Pidana Pencucian Uang (TPPU). Sebelum berlakunya Tindak Pidana Pencucian Uang (TPPU), perlindungan atas hak-hak pelapor diatur dalam Undang-Undang Nomor 13 Tahun 2006 Tentang Perlindungan Saksi dan Korban. ${ }^{12}$

Secara khusus perlindungan bagi Pelapor dan Saksi tindak pidana pencucian uang telah diatur dalam Peraturan Pemerintah Nomor 57 Tahun 2003 tentang Tata Cara Perlindungan Khusus Bagi Pelapor dan Saksi Tindak Pidana Pencucian Uang. Ketentuan teknis dalam pemberian perlindungan bagi pelapor dan saksi dalam tindak pidana

12 Secara khusus Undang-Undang Perlindungan Saksi dan Korban tidak mengatur mengenai perlindungan bagi pelapor, tetapi ketentuan yang ada dalam UndangUndang ini berlaku untuk saksi dan korban semua tindak pidana termasuk tindak pidana pencucian uang. 
Media Komunikasi dan Informasi Hukum dan Masyarakat

pencucian uang kemudian diatur melalui Peraturan Kepala Kepolisian Negara Republik Indonesia (KAPOLRI) Nomor 17 Tahun 2005 tentang Tata Cara Pemberian Perlindungan Khusus terhadap Pelapor dan Saksi dalam Tindak Pidana Pencucian Uang.

Ketentuan mengenai perlindungan khusus ditegaskan dalam pasal 2 Peraturan Pemerintah Nomor 57 Tahun 2003 menegaskan bahwa setiap pelapor dan Saksi dalam perkara tindak pidana pencucian uang wajib diberikan perlindungan khusus baik sebelum, selama maupun sesudah proses pemeriksaan perkara. Bentuk perlindungan khusus yang dimaksud adalah perlindungan atas keamanan pribadi dari ancaman fisik dan mental, perlindungan terhadap harta, perlindungan berupa kerahasiaan dan penyamaran identitas, dan memberikan keterangan tanpa bertatap muka (konfrontasi) dengan tersangka atau terdakwa pada setiap tingkatan pemeriksaan perkara. ${ }^{13}$

Lebih lanjut mengenai teknis pelaksanaannya, telah dikeluarkan Peraturan KAPOLRI No. 17 Tahun 2005 tentang Tata Cara Perlindungan Khusus Terhadap Pelapor dan Saksi Dalam Tindak Pidana Pencucian Uang. Perlindungan khusus menurut Peraturan KAPOLRI ini adalah suatu bentuk perlindungan yang diberikan oleh aparat Kepolisian Negara Republik Indonesia untuk memberikan rasa aman terhadap pelapor atau saksi dari kemungkinan yang membahayakan diri jiwa dan atau hartanya termasuk keluarganya. Pemohon perlindungan khusus adalah pelapor, saksi, PPATK, Penyidik, Penuntut Umum atau hakim.

Pengaturan mengenai perlindungan bagi Pelapor dan Saksi dalam Undang-Undang 2003.
Nomor 8 tahun 2010 tentang Pencegahan dan Pemberantasan Tindak Pidana Pencucian Uang terdapat didalam Bab IX yaitu terdapat pada pasal 83-87. Undang-Undang Tindak Pidana Pencucian Uang (TPPU) menegaskan pengaturan perlindungan-perlindungan hukum yang diberikan kepada pihak pelapor atas jasanya yang melaporkan transaksi keuangan mencurigakan terkait tindak pidana pencucian uang. Bentuk perlindungan hukum pertama yang diberikan Undang-Undang Tindak Pidana Pencucian Uang (TPPU) adalah kewajiban hukum bagi Pusat Pelaporan dan Analisis Transaksi Keuangan (PPATK), penyidik, penuntut umum serta hakim untuk merahasiakan identitas dari pelapor Tindak Pidana Pencucian Uang (TPPU)..$^{14}$

\section{Kesimpulan \& Saran}

\section{A. Kesimpulan}

1. Notaris dilibatkan sebagai pihak pelapor dalam pencegahan dan pemberantasan tindak pidana pencucian uang karena belum maksimalnya pencegahan dan pemberantasan tindak pidana pencucian uang di Indonesia dengan modus pencucian uang yang semakin canggih karena memanfaatkan profesi notaris sebagai sarana pencucian uang oleh pelaku pencucian uang untuk memuluskan aksinya terhadap uang yang diperoleh dari hasil kejahatan dan dengan dilibatkannya notaris sebagai pihak pelapor maka menambah kemudahan bagi PPATK untuk mengungkap tindak pidana pencucian uang yang terjadi di Indonesia.

2. Pelaksanaan pelaporan oleh notaris sebagai pihak pelapor tindak pidana pencucian

14 Pasal 83 Ayat (1) Undang-Undang Nomor 8 Tahun 2010 Tentang Tindak Pidana Pencucian Uang (TPPU). 
Media Komunikasi dan Informasi Hukum dan Masyarakat

uang. Pertama pihak pelapor wajib menerapkan prinsip mengenali pengguna jasa kemudian untuk melaksanakan pelaporan kepada PPATK notaris wajib melakukan registrasi dan pengisian laporan dengan menetapkan petugas pelaporan, melakukan registrasi melalui aplikasi Gathering Reports and Information Processing System (GRIPS) laporan transaksi keuangan mencurigakan wajib memuat informasi paling sedikit mencakup orang-perorangan, korporasi, rincian transaksi yang dilaporkan, informasi lainnya dan identitas pemilik sebenarnya (Beneficial Owner) orang-perseorangan atau korposasi yang dilaporkan.

3. Perlindungan hukum terhadap notaris sebagai pihak pelapor tindak pidana pencucian uang yaitu notaris tidak dapat dituntut baik secara perdata maupun pidana atas pelaksanaan kewajiban pelaporan atas tindak pidana pencucian uang yang dilakukan oleh kliennya berdasarkan Pasal 29 Undang-Undang Nomor 8 Tahun 2010 Tentang Pencegahan dan Pemberantasan Tindak Pidana Pencucian uang serta demi terjaminnya perlindungan hukum dan kepastian hukum bagi profesi Notaris juga di tegaskan dalam Pasal 2 Peraturan Pemerintah Nomor 57 Tahun 2003 menegaskan bahwa setiap pelapor dan Saksi dalam perkara tindak pidana pencucian uang wajib diberikan perlindungan khusus baik sebelum maupun sesudah proses pemeriksaan perkara. Perlindungan hukum terhadap Notaris ini bertujuan, agar hak dan kewenangan maupun kewajiban Notaris dalam menjalankan tugasnya sebagaimana diberikan oleh UndangUndang Jabatan
Notaris dan Kode Etik dilakukan berdasarkan ketentuan yang berlaku, baik itu berdasarkan hukum maupun berdasarkan moral dan etika profesi.

\section{B. Saran}

1. Diharapkan Notaris aktif dalam melakukan pencegahan dan pemberantasan tindak pidana pencucian uang sebagai pihak pelapor.

2. PPATK perlu terus melakukan perkembangan terhadap aplikasi Gathering Reports and Information Processing System (GRIPS) agar notaris bisa lebih praktis dalam melakukan pelaporan yang di input ke pada PPATK.

3. Diharapkan pemerintah dan dewan perwakilan rakyat untuk secara tegas membuat aturan notaris sebagai pihak pelapor dalam pencegahan dan pemberantan tindak pidana pencucian uang. 
Media Komunikasi dan Informasi Hukum dan Masyarakat

\section{DAFTAR PUSTAKA}

Bismar Nasution, Rezim Anti Money Laundering di Indonesia, Bandung, BooksTerrace \& Library, 2008.

Fithriadi Muslim, Journal on anti money Laundering ,"Fungsi Laporan Transaksi Keuangan Mencurigakan Dalam Pencegahan Dan Pemberantasan Tindak Pidana Pencucian Uang", Depok, PusatKajian Anti PencucianUang Indonesia Indonesia Research Center for AML- CFT (IRCA), 2013.

Nicholas Clark, The Impact of Recent Money Laundering Legislation on Financial Intermediaries,Dick J. Int'I.L, vol. 14.

R. Wiyono, Pembahasan Undang-Undang Pencegahan dan Pemberantasan Tindak Pidana Pencucian Uang, Sinar Grafika, , Jakarta, 2014.

Sutan Remy Sjahdeini, Seluk-Beluk Tindak Pidana Pencucian Uang dan Pembiayaan Terorisme, Jakarta, Pustaka Utama Grafiti, 2007.

Yunus Husein, Journal On Anti Monye Laundering "Urgensi Gatekeeper Sebagai Pelapor Dalam Rezim AntiPencucian Uang Indonesia" Depok, Pusat Kajian Anti Pencucian Uang Indonesia Indonesia Research Center For Aml-Cft (Irca), 2013. 